\title{
Introducing the new President, Professor R. E. Kendell
}

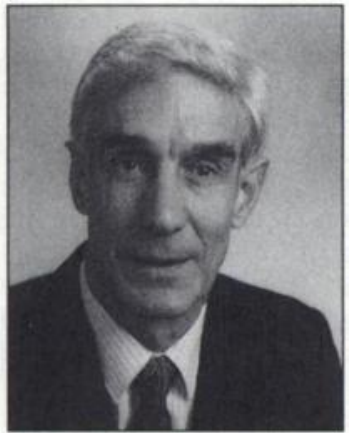

R. E. Kendell

Soon after I was elected president last autumn I was invited to write an article, introducing myself to the College's Members and Fellows and outlining my plans and aspirations for the College.

\section{The past}

As I suspect that to many Members of the College I am a Scottish professor they have never set eyes on who edits a rather large, expenstve textbook, I probably ought to start by describing my own background.

After a few years' experience of general medicine and neurology I trained as a psychiatrist at the Maudsley Hospital in the early 1960s. So I proudly bear the indelible stamp of Aubrey Lewis. After a year as Michael Gelder's senior registrar and writing a thesis on the classification of depressions I joined the US/UK Diagnostic Project, a well funded research team set up to investigate what then appeared to be profound Anglo-American differences in the prevalence of schizophrenia and manic depressive illness. Then in 1970, after three absorbing years of full-time clinical research and 18 months running a psychiatric ward and teaching at the Untversity of Vermont in the wooded hills of New England, I was appointed to a readership at the Institute of Psychiatry. By this time I had become deeply interested in a range of issues concerned with diagnosis and classification and I wrote a little book on The Role of Diagnosis in Psychiatry while running a general admission ward at the Bethlem Royal Hospital and trying to organise a coherent training programme for the Joint Hospitals' first year registrars.
In 1974 I was appointed to the chair of psychiatry in Edinburgh and I have lived and worked in that splendid city ever since. At that time Edinburgh was the largest and best known department of psychiatry in the UK apart from the Maudsley Hospital itself. It had its own seven storey building, three established chairs, and its own wards, laboratories and library: and for the next 12 years I was busy running an acute admission ward, trying to create a really good three-year training programme for all the psychiatric trainees in south east Scotland and trying to maintain a genuine involvement in clinical and epidemiological research. After Alistair Forrest's untimely death I was also asked to take over his Companion to Psychiatric Studies and eventually edited the 1983, 1988 and 1993 editions with Andrew Zealley. The Edinburgh University Department of Psychiatry and the Royal Edinburgh Hospital possessed between them an impressive wealth of talent and it was possible to produce an authoritative postgraduate textbook covering the whole of psychiatry without needing to involve many external contributors. I also discovered that although editing a large textbook was no light task it was an excellent way of ensuring that I kept abreast of current developments across the field myself.

I was involved in College affairs from an early stage. Indeed, I was a member of the Clinical Tutors' Subcommittee of the Education Committee of the old Royal Medico-Psychological Association before the College obtained its Royal Charter, and so became one of the founding members of the original Education Committee. In 1975 I also became one of the College's representatives on the Joint Committee on Higher Psychiatric Training and ended up chairing its General Psychiatry Subcommittee and conducting several of the crucial first inspections of many senior registrar training programmes throughout the UK. Subsequently I served for three years on the Court of Electors and its Examinations Subcommittee and so learnt a good deal about the College's vital role in raising the quality of psychiatric training and the reliability and relevance of its own Membership examination.

In 1986 I was elected Dean of the Edinburgh Medical School and for the next four years much of my time and energy were devoted to finding out how a big university functioned, protecting my Faculty from potential predators and trying, in a 
now hackneyed phrase, to help it become leaner and fitter', and better able to cope with the challenges posed by the Untversity Funding Council's Research Selectivity Exercise and the urgent need for curricular change. During these four years I had to ask one of my colleagues to look after my ward, but I kept up most of my undergraduate and postgraduate teaching, my out-patient clinic and some epidemiological research; and when my term as dean was over I happily returned to my department and my ward and started planning a long delayed sabbatical year at the Centre for Advanced Studies in the Behavioural Sciences at Stanford Untversity in California. Then in the summer of 1991 I found myself, quite unexpectedly, faced with the possibility of becoming Chief Medical Officer in The Scottish Office for the next five years. After some soul searching and domestic dismay I cancelled my sabbatical year, resigned from the College Council before attending a single meeting, and became a civil servant and the Secretary of State for Scotland's principal medical adviser. As a result I have had little contact with psychiatry or with the College for the last five years. Instead, I have learnt a good deal about public health, about the Department of Health and Whitehall, and about the complicated structure of British medicine - the Royal Colleges, the British Medical Association, the General Medical Council and the 10000 Scottish doctors they all aspire to represent. I have also had to get involved in so many individual clinical problems, from Hepatitis $C$ to teenage pregnancy to Creutzfeldt-Jakob disease, that at times I have almost persuaded myself I could pass finals again.

\section{The future}

I succeed Flona Caldicott as president at the College's Annual Meeting this month, but I will not be retiring from my post in The Scottish Office until the end of September. This means, I am afraid, that for my first ten weeks in office I will not be able to devote as much time as I should to College affairs and will have to lean rather heavily on the other College officers, and perhaps on Dr Caldicott as well. Thereafter, though, my wife (a consultant anaesthetist) and I will both be retired and I will be able to devote myself wholeheartedly to the College.

I will start my term of office deeply conscious of the fact that I am badly out of touch, not only with the detailed workings of the College but also with psychiatry and psychiatrists. If only for this reason I will want to spend several months listening to other people before I even contemplate any grand new initiatives. I come to the presidency, of course, with a rather unusual background. I comfort myself, though, with the thought that, although I will be ignorant about many important things, several other people in the College will know the things I don't know. And I will know some important things about British medicine and its leading figures, and about the UK Health Departments, which they do not know. I have also had the opportunity in the last five years to look at British psychiatry from the outside, as one discipline, one College, among many; and you notice quite different things looking in from outside from those you see looking outside from within. I have also, of course, seen the profound changes that have taken place since 1989 in the National Health Service (NHS) and in the care of the mentally ill from a quite different perspective from that of most practising psychiatrists. Care in the community and the disappearance of the psychiatric hospitals which were our flefdom for over a hundred years create what Americans call 'a whole new ball game'. Several different professions - general practitioners, psychiatrists, social workers, psychiatric nurses, clinical psychologists and a motley array of counsellors - are already jostling together in this new world, and while they compete for power and influence, cost conscious NHS managers are going to be pondering questions of 'skill mix' and wondering how the needs of what I prefer to call people with psychiatric disorders and they call people with mental health problems can be met most economically. Psychiatrists, and the College, are going to need to think carefully about their future roles in this unstable and cost-driven world, and do their best to ensure that their ambitions are realistic and that they and their successors possess the skills they will need in order to achieve those ambitions. I suspect that this may be the most fundamental and important issue both for me and for my fellow College officers over the next few years. We may also find, too, that some time after the next general election the new government wishes to revise the increasingly dated Mental Health Acts.

R. E. KENDELL 